established during the disease in four previously healthy adults and one child with a mononucleosis-like disease without a positive heterophil agglutination test. No antibodies were demonstrable in the first sample from three patients.

The disease was characterized by protracted fever and absence of tonsillitis. Enlargement of the lymph nodes was seen in only one patient. The tests for liver function gave abnormal results in all the cases. Leucocytosis, relative and absolute lymphocytosis, and the appearance of abundant atypical lymphocytes were features of the haematological pattern.

No significant rise of the C.F. antibody titre to the cytomegalovirus was demonstrable in a single case among 19 patients suffering from infectious mononucleosis with a positive heterophil agglutination test or among 130 patients with various acute infectious diseases. A high titre, however, was found in two patients with infectious mononucleosis, there being a significant decrease of the titre later, after the disease was over, and in two patients of the control material, both of whom had a chronic debilitating disease in addition to their acute infection.

We are indebted to Dr. P. Halonen, now Professor of Virology, University of Turku, for making available the "AD 169 " strain of cytomegalovirus and for helpful advice, and to the following virologists and microbiologists for their advice and co-operation in the study of the aetiology: Professor N. Oker-Blom, Department of Virology, University of Helsinki ; Drs. O. Wager and E. Jansson, Microbiological Laboratory, Aurora Hospital ; and Dr. K. Cantell, State Serum Institute. We also express our gratitude to Mrs. P. Leino, Mrs. P. Koivunen, and Miss S. Keränen for technical assistance.
ADDENDUM.- In addition to the rise in the titre of complement-fixation antibodies, a significant rise in the titre of neutralizing antibodies to the cytomegalovirus has been established in all the five patients with a mononucleosis-like disease discussed above. Six further cases belonging to the category "infectious mononucleosis without a positive heterophil agglutination test" have been studied in the ensuing three months. In four of these-adults with the typhoidal type of the disease, without tonsillitis, and without enlargement of lymph nodes-a significant rise of complement-fixation antibodies to the cytomegalovirus has been demonstrated. On the other hand, no complement-fixation antibodies to the cytomegalovirus were demonstrable in the other two-children under 3 years of age, both of whom had exudative pharyngitis and enlarged lymph nodes.

\section{REFERENCES}

Belfrage, S. (1962). Acta med. scand., 171, 531.

Carlström, G. (1965)... Acta. paediat. scand., 54, 17.

Halonen, P., and Kääriäinen $\mathrm{L}$ to be published.

Hanshaw, J. B., Betts, R. F., Simon, G., and Boynton, R. C. (1965) New Engl.' Ұ. Med., 272, 602.

Hoagland, R. J. (1955). Amer. F. med. Sci., 229, 262

Hobson, F. G., Lawson, B., and Wigfield, M. (1958). Brit. med. F., 1 845 .

Rowe, W. P., Hartley, J. W., Waterman, S., Turner, H. C., and Huebner, R. J. (1956). Proc. Soc. exp. Biol. (N.Y.), 92, 418.

Shubert, S., Collee, J. G., and Smith, B. J. (1954). Brit. med. F., 1, 671 Siim, J. (1960). In Human Toxoplasmosis, pp. 53-79. Wiliams \& Wilkins, Baitimore.

Weller, T. H., and Hanshaw, J. B. (1962). New Engl. 7. Med., 266, 1233.

- 1 and Scott, D. E. (1960). Virology, 12, 130.

- Macauley, J. C., Craig, J. M., and Wirth, P. (1957). Proc. suc. exp. Biol. N.Y.', 94, 4 .

Wong, T. W., and Warner, N. E. (1962). Arch. Path., 74, 40 s.

\title{
Hereditary Coproporphyria with Acute Intermittent Manifestations
}

\author{
H. D. BARNES,* M.SC., PH.D. ; NORMAN WHITTAKER, † M.A., M.D., M.R.C.P.
}

Brit. med. F., 1965, 2, 1102-1104

Detailed studies of cases of porphyria in recent years have shown the existence of two distinct forms of this disorder in which patients are liable to develop acute intermittent abdominal crises. Both forms are familial, and their patterns of inheritance indicate an autosomal dominant genetic basis. The first of these, widely known as acute intermittent porphyria, is prevalent in Sweden, where it has been intensively studied by Waldenström $(1937,1957)$ and Waldenström and Haeger-Aronsen (1963); the second form, for which the name variegate porphyria has been adopted, has its highest incidence in South Africa, where it has been studied and reported by Dean and Barnes (1955, 1959), Eales (1963), and by Eales et al. (1963). The principal differential features can be tabulated as follows :

\section{Acute Intermittent}

Intermittent episodes of acute abdominal pain, neurological disorder, and psychotic disturbance order, and psychouc disturbance in different proportions.

Urinary excretion of aminolaevulic

acid (A.L.A.) and porphobilinogen (P.B.G.)-porphyrin precursors - increased during attacks, with a marked tendency 10 rersist into remissions. Latent cases can be detected by appropriate tests.

stool porphyrins normal in the maiority of patients. The slight increases sometimes found can increases sometimes found can
probably be attributed to other causes.
The patients whose cases are reported below belong to one family, and the findings are not in strict accord with either of the above groups. The propositus suffered an acute porphyric episode towards the end of 1962 and on recovery his urine and stool were analysed in detail for porphyrins and precursors. Specimens were also obtained from all four of his sibs, and three of them showed the same anomalous pattern of excretion. The methods used in these analyses were those described by Rimington (1961) for porphyrins, and by Mauzerall and Granick (1956) for aminolaevulic acid and porphobilinogen.

\section{Case Report}

A man aged 22 was admitted to the North Middlesex Hospital on the surgical side under the care of $\mathrm{Mr}$. T. M. Hennebry on 1 November 1962, with a diagnosis of constipation and possibly appendicitis. He had had an attack of tonsillitis two to three weeks previously, and since then had been taking Soneryl sleepingtablets. His father, one brother, and one sister had been subject to abdominal pains, for which there was no definite diagnosis.

Clinical examination revealed an afebrile patient with a pulse of 110 and slight tenderness in the right iliac fossa. Hard faeces were felt in the rectum and there was tenderness on the right side of the pelvis ; his bowels had not opened for three days before admission. Five more days passed without evacuation of faeces;

\footnotetext{
* Medical Research Council Grantholder, St. Mary's Hospital Medical School, London.

† Consultant Physician, North Middlesex Hospital, London.
} 
by this time the caecum was palpable and abdominal $x$-ray examination showed scybala within it. On the fourth hospital day he did not pass urine, and only a few drops of pink fluid were drawn off from the bladder by catheter. The urine did not contain albumin, but scanty pus cells and a sparse growth of Escherichia coli were demonstrated. The blood-pressure had risen from 130/80 to 200/ 140 , but no oedema was noted. Butobarbitone had been given in hospital, but this was withdrawn pending laboratory results to decide between diagnosis of acute nephritis and acute intermittent porphyria.

On the fifth day he was passing urine freely; this became portwine in colour after standing and contained copious porphobilinogen and coproporphyrin. Subsequent convalescence was uneventful, the constipation and abdominal pain subsiding and the blood-pressure falling to normal levels.

In the past two years he has avoided barbiturates, and states that he has had wind pains only.

Excreta from his eldest brother (aged 32) showed porphyrins within normal limits; the findings for the propositus and the other three sibs are given in the Table. Determinations of the precursors were begun within an hour of the urine being passed. Specimens of blood were obtained from the sister aged 27 and the propositus in August 1964. Erythrocyte coproporphyrin and protoporphyrin were not increased and porphyrin was not detected in the plasma of either specimen.

Laboratory Findings in Excreta of Affected Members

\begin{tabular}{|c|c|c|c|c|c|c|c|}
\hline \multirow{5}{*}{$\begin{array}{l}\text { Sister }(30) \\
\text { March } 1963 \\
\text { May } \\
\text { August } 1964\end{array}$} & \multirow{5}{*}{$\because \ddot{x}$} & \multicolumn{4}{|c|}{ Urine } & \multicolumn{2}{|c|}{ Stool } \\
\hline & & \multicolumn{2}{|c|}{$\begin{array}{c}\text { A.L.A. P.B.G. } \\
\text { mg./1. }\end{array}$} & \multicolumn{2}{|c|}{ Uro. $\left.\right|_{\mu \mathrm{g} . / 1 .} ^{\text {Copro. }}$} & \multicolumn{2}{|c|}{$\begin{array}{c}\text { Copro. Proto } \\
\mu \mathrm{g} . / \mathrm{g} . \text { dry wt }\end{array}$} \\
\hline & & & & & & & \\
\hline & & 0.6 & 0.2 & -230 & - & 1,000 & $-\frac{1}{-0}$ \\
\hline & & & & - & 一 & 1,960 & 52 \\
\hline March 1963 & 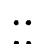 & $\overline{2.3}$ & 0.8 & \multicolumn{2}{|c|}{ Increased } & 1,310 & 68 \\
\hline $\begin{array}{l}\text { May } \\
\text { August 19”64 } \\
\text { Brother }\end{array}$ & $\because$ & 3.0 & 0.6 & $\overline{132}$ & 56 & $1, \overline{340}$ & 96 \\
\hline $\begin{array}{l}\text { Brother (25) } \\
\text { March } 1963\end{array}$ & .. & & & 150 & 400 & 770 & 23 \\
\hline $\begin{array}{l}\text { May } \\
\text { Propositus }\end{array}$ & & 5.4 & 1.7 & & & - & \\
\hline March 1963 & . & $\overline{5 \cdot 2}$ & $\overline{1.6}$ & 353 & 610 & 1,106 & 25 \\
\hline $\begin{array}{l}\text { August } 19364 \\
\text { Upper normal limits }\end{array}$ & $\because \ddot{0}$ & 13 & $\begin{array}{c}16 \\
2\end{array}$ & $\begin{array}{r}457 \\
25\end{array}$ & $\begin{array}{r}2,910 \\
200\end{array}$ & $\begin{array}{r}2,400 \\
25\end{array}$ & $\begin{array}{l}21 \\
50\end{array}$ \\
\hline
\end{tabular}

The coproporphyrins extracted from stools of the two sisters and the propositus were compared by Eriksen's (1958) method of paper chromatography with markers obtained from stools from a case of erythropoietic (congenital) porphyria (isomer I) and from cultures of Corynebacterium diphtheriae (isomer IID). This indicated that the pigment from our three subjects was predominantly isomer III.

\section{The Family}

The following clinical information was obtained about the sibs. The sister aged 30 had had obscure episodes of periumbilical pain radiating to the right iliac fossa in 1960 and 1961. Each lasted four to six hours and was accompanied by vomiting, but no physical signs were elicited.

The sister aged 27 denied having abdominal pain apart from dysmenorrhoea. She was given sleeping-tablets at her first confinement in hospital without ill effects; her second confinement, in June 1964, was also free from untoward events. Her appendix had been removed 10 years ago for genuine appendicitis, an intravenous injection being given for induction of anaesthesia. Her son aged 3 years recently had one episode of acute abdominal pain; no excess of porphyrin was found in his stool a few weeks later. The brother aged 25 was admitted to hospital with upper abdominal colic in 1962, but this had subsided by the time he reached the ward and physical examination was then normal. No abnormality was shown on plain $x$-ray or barium-meal examination. A tentative diagnosis of cholecystitis was made in 1963 for pain at the base of the right lung; this subsided in four to five days.

The younger sister had been treated for scabies, but there was no knowledge of other skin lesions. No member of the sibship has had neurological lesions or psychoses.
The mother of these sibs had died some years previously of tuberculosis, to which several members of her family had been subject. Since her death their father has had only rare contacts with his children, and it remains a matter for regret that he could not be traced for study, since they state that he had complained of intermittent abdominal pain. Two of his sisters, aged 63 and 65 , were located. They provided specimens of urine and stool, in which the levels of porphyrins and precursors were within normal limits.

\section{Comment}

The marked elevation of coproporphyrin in faeces from these four subjects demarcates them from acute intermittent porphyria, in which stool porphyrins are usually normal, and from variegate porphyria, in which both coproporphyrin and protoporphyrin fractions are increased in the stool. The propositus experienced a typical episode of acute porphyria and fortunately recovered despite the continued administration of barbiturates, without developing neurological complications. Constipation was a striking feature of the clinical picture and was so pronounced that the caecum became palpable, and a plain abdominal $x$-ray examination showed this organ to be full of scybala. Constipation, abdominal pain, and vomiting were stressed as an important clinical triad in acute porphyria by Günther as long ago as 1922 . Subsequent authors (Markovitz, 1954 ; Goldberg and Rimington, 1963 ; Eales, 1963) have recorded its occurrence in $50 \%$ to $80 \%$ of cases. In retrospect porphyria remains the probable explanation for the recurrent abdominal colic in the brother and sister of our patient. Urinary porphobilinogen was within normal limits in most of the specimens examined ; latent cases are therefore unlikely to be detected by tests for this metabolite.

Several reports are available of markedly increased coproporphyrin excretion, but none of these subjects had accompanying symptoms suggestive of porphyria. Dobriner (1936) recovered relatively large amounts of coproporphyrin (isomers I and III) from faeces of his patient. Urinary coproporphyrin was also increased. Watson et al. (1949) reported two unrelated cases of idiopathic coproporphyrinuria. Faecal excretion was also greatly increased and the pigment was mainly isomer III. Uroporphyrin was not detected in urine from either patient, and urine from three sibs of one of them was normal with respect to coproporphyrin. Berger and Goldberg (1955) found high levels of coproporphyrin III in urine and stool from a 10-year-old boy with rickets and riboflavine deficiency. Dr. C. Ziegler has recently stated (personal communication) that considerable increases in aminolaevulic acid, porphobilinogen, and uroporphyrin were found in urine from this patient during the first half of 1964 ; there were, however, no corresponding clinical symptoms. His parents are first cousins, and at the time of the first study both excreted excess of coproporphyrin in urine and stool; urine from a paternal aunt also contained an excess of this pigment. Cowger and Labbe (1965) refer, without further details, to a child of 7 years with a family history of hereditary coproporphyria in whom acute intermittent porphyria was apparently induced by treatment with anticonvulsants and tranquillizers.

It remains a matter for speculation whether the findings in our group and the other patients referred to can be attributed to the same anomaly of porphyrin metabolism. The name hereditary coproporphyria, proposed by Berger and Goldberg (1955), seems most appropriate for the condition described, and the more recent observations indicate that it should no longer be regarded as a benign disorder.

\section{Summary}

Excessive excretion of coproporphyrin is reported in four members of a sibship of five. One of them had suffered a 
typical acute porphyric episode and two others had had unexplained abdominal colics.

We wish to thank Drs. B. A. Lees, R. G. Pett, and L. M. Rubens for information about their patients, and Drs. G. H. Renton and W. R. John for making contact with the relations. Laboratory facilities were made available to H. D. B. by Professor A. Neuberger, F.R.S.

\section{REFERENCES}

Berger, H., and Goldberg, A. (1955). Brit. med. f., 2, 85 Cowger, M. L., and Labbe, R. F. (1965). Lancet, 1, 88.
Dean, G., and Barnes, H. D. (1955). Brtt. mea. F., 2, 89. Dobriner. (1959): S. Afr. med. F., 33, 246

Dobriner, K. (1936). Proc. Soc. exp. Biol. (N.Y.), 35, 175. Eales, L. (1963). S. Afr. F. Lab. clin. Med., 9, 151.

-Dowdle, E. B., Saunders, S. J., Sweeney, G. D. (1963). Ibid., 9, 162.

Eriksen, L. (1958). Scand. f. clin. Lab. Invest., 10, 319.

Goldberg, A., and Rimington, C. (1963). Diseases of Porphyrin Metabolism. Thomas, Springfield, Illinois.

Günther H. (1922). Ergebn. allg. Path. path. Anat., 20, 607.

Günther, H. (1922). Ergebn. allg. Path. path. Anat.

Markovitz, M. (1954). Ann. intern. Med., 41, 1170.

Mauzerall, D., and Granick, S. (1956). F. biol. Chem., 219,
Rimington, C. (1961). Ass. Clin. Path. Broadsheet No. 36.

Waldenström, J. (1937). Acta med. scand., Suppl. No. 37.

- (1957). Amer. f. Med., 22, 758.

and Haeger-Aronsen, B. (1963). Brit. med. F., 2, 272.

Watson, C. J., Schwartz, S., Schulze, W., Jacobson, L. O., and Zagaria, R. (1949). f. clin. Invest., 28, 465.

\section{Preliminary Communications}

\section{Studies on Antibody Levels during \\ Vaccination of Rhesus Monkeys against Plasmodium knowlesi}

Brit. med.F., 1965, 2, 1104-1106

The fluorescent antibody technique has been applied extensively in recent years to the serology of malaria. It has been used to study the antigenic relationships between species of malaria parasites (Tobie and Coatney, 1961; Voller, 1962, 1964 ; Collins et al., 1965), for the measurement of antibody produced during experimentally induced malaria infections (Kuvin et al., 1962 ; Tobie and Coatney, 1961 ; Collins et al., 1964), and for field studies in malaria-endemic regions of the world (Voller and Bray, 1962 ; Voller and Wilson, 1964 ; Gebbie et al., 1964 ; Marsden et al., 1965 ; McGregor et al., 1965).

Serum from immune patients or animals contains antibody which by passive transfer will reduce parasitaemia and bring about clinical cure of acute infections (McGregor and Cohen, 1963). However, the relationship between protective antibody and the antibody measured by the fluorescent antibody technique is still not clear. In some cases strong serological crossreactions may occur between different species of malaria although solid immunity to one confers no protection against the other, indicating that the antibody being measured probably has no protective function. In other cases, particularly in malaria-endemic areas, the elevation of gamma-globulin has been proved to be at least partly due to malaria (Gilles and McGregor, 1959), and the levels of antibody measured by the fluorescent antibody technique correspond closely to the classical concepts of malarial immunity (Voller and Bray, 1962 ; McGregor et al., 1965).

The purpose of the present investigation was to try to relate the serum protein changes and the fluorescent antibody titres to the degree of protection obtained by vaccination of rhesus monkeys against Plasmodium knowlesi ; that is, to relate these serological changes to the functional immune response.

\section{Materials AND Methods}

Rhesus monkeys were given two intramuscular injections of vaccine with an interval of six to eight weeks between injections. The formalized vaccine used was either concentrated infected monkey red blood cells or the malaria parasites freed from the host cells by means of a haemolytic antiserum (Targett and Fulton, 1965 ; Targett, in preparation). The first injection was given with Freund's complete adjuvant, the second with the incomplete adjuvant. The monkeys were challenged about six weeks after the second vaccination.

Serum protein changes were measured as described earlier (Targett and Fulton, 1965). Sera were tested by the indirect fluorescent antibody technique for malaria, as described fully by Voller (1964).

\section{Results}

Fig. 1 shows the parasitaemias developed after challenge in two groups of monkeys which were successfully protected.

Fig. 2 shows the serum protein changes that occurred in the four monkeys vaccinated with infected red blood cells. Antibody levels of sera from this second group of monkeys were measured by the fluorescent antibody technique, and Fig. 3 shows the relationship for two of the monkeys between gammaglobulin levels and fluorescent antibody technique titres during the vaccination period.

Further vaccination experiments were carried out with a similar procedure but with free parasites as vaccine. Groups

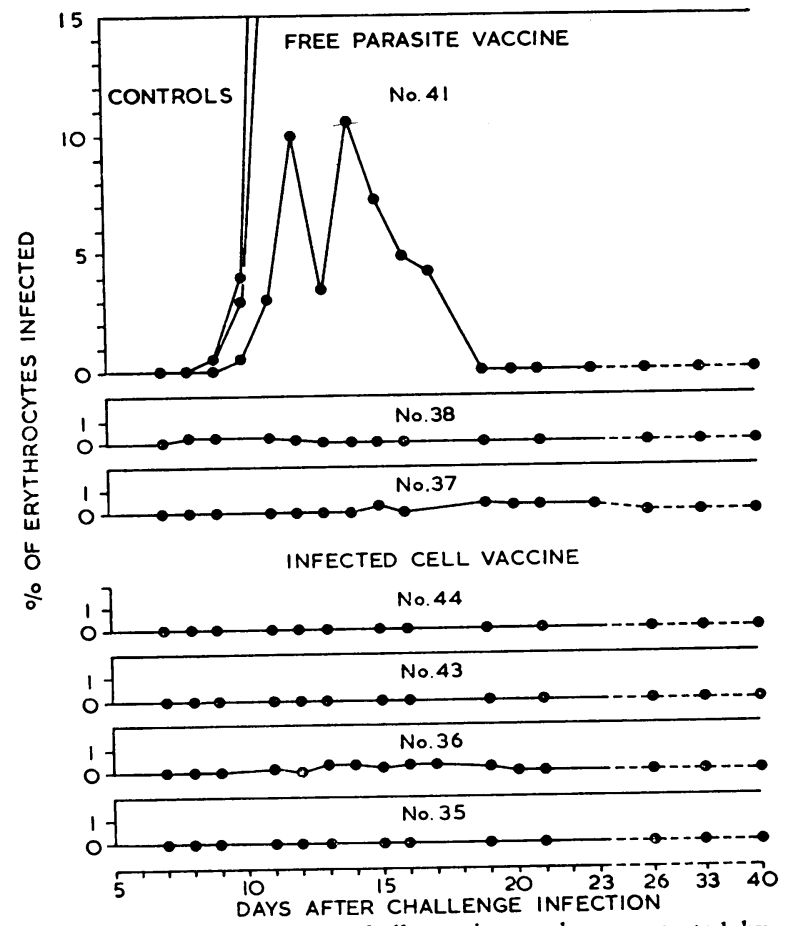

FIG. 1.-Parasitaemia after challenge in monkeys protected by vaccination. 